\title{
Optimalisasi Kader Sebagai Pmo (Petugas Minum Obat) dalam Mengkonsumsi Tablet Fe terhadap Pencegahan Anemia Berbasis Android di wilayah Kerja Puskesmas Simpang Kawat
}

\author{
Lismawati ${ }^{1}$, Rica Tri Septinora ${ }^{2}$ \\ 1,2Universitas Adiwangsa Jambi \\ jl sersan muslim rt 24 kelurahan tehok kebun kopi kec. Jambi selatan \\ correspondence e-mail: neng_lism4w4ti@yahoo.com
}

\begin{abstract}
Abstrak. Anemia akibat kekurangan gizi ibu hamil di Indonesia sebanyak 70\%. Pada pengamatan lebih lanjut menunjukkan bahwa kekurangan anemia yang diderita masyarakat adalah asupan Fe yang dapat diatasi dengan pemberian zat besi secara teratur. penelitian merupakan penelitian Analitik dengan Desain penelitian quasi eksperiment dengan menggunakan kelompok kontrol yang bertujuan untuk mengetahui perbedaan kadar hemoglobin sebelum dan sesudah diawasi oleh kader sebagai PMO (Petugas Minum Obat) dalam mengkonsumsi tablet Fe terhadap pencegahan anemia berbasis Android. Penelitian ini dilakukan dilakukan pada 11 Juli s/d 15 Agustus 2019. Sampel dalam penelitian ini adalah 30 responden sebagai kelompok eksperimen dan 30 responden sebagai kelompok control, diawali dengan pengukuran $\mathrm{Hb}$ pada responden kemudian pemantauan pada kelompok yang diberikan yang diberikan intervensi oleh kader sebagai PMO melalui aplikasi berbasis android dan kemudian diukur kembali kadar $\mathrm{Hb}$ responden. Data penelitian dianalisis secara univariat dan bivariat melalui uji $t$ test dengan $\alpha=0,05$. Hasil penelitian pada analisis univariat menunjukan rata-rata umur ibu, paritas dan usia kehamilan adalah homogen dengan $p$-value $>$ 0,05 yang berarti tidak ada perbedaan karakteristik pada kelompok kader sebagai PMO dan tanpa kader sebagai PMO, dan pada analisis bivariat didapatkan $p$-value $<0,001$ sehingga dapat dismpulkan bahwa terdapat perbedaan selisih kadar $\mathrm{Hb}$ pada kelompok kader sebagai PMO dan tanpa kader sebagi PMO. Sehingga dapat diinterpretasikan bahwa kader sebagai PMO Optimal terhadap peningkatan kadar $\mathrm{Hb}$ dalam pencegahan anemia ibu hamil. Upaya yang dilakukan terhadap pencegahan anemia salah satunya dengan mengaktifkan semua tenaga kesehatan termasuk kader dalam meningkatkan keteraturan dalam mengkonsumsi tablet Fe pada ibu hamil
\end{abstract}

Kata kunci: Anemia; Kader; kadar Hb; Tablet Fe

Abstract. Anemia due to malnutrition of pregnant woman in Indonesia is $70 \%$. On further observation, shows that anemia that suffered by the community due to lake of Fe intake which is can be solved by consume iron regulary. This research is analytic research with quasi experiment design which uses control group which aims to know the difference of hemoglobin level between before and after supervised by cadres as a PMO (Petugas Minum Obat) in consuming Fe tablet agains anemia prevention android based. This research was on July 11 until August 15, 2019. The sample of the study are 30 respondents as the experiment group and 30 respondents as the control group. Begin with the mesurement of respondent's hemoglobin, then the monitoring given intervention by cadres as the PMO through an android based application. After that, the respondent's hemoglobin level will be measured again. The data of this research are analized by univariate and bivariate $t$-test with $a=0,05$. The reseach results on unvariate analysis shows the average age af the mother, parity and gestational age are homogeneus with the $p$-value $>0,05$ which means nothing difference on the characteristic of the cadres as the PMO and without cadres as the PMO. Beside that, the result on bivariate analysis shows that $p$-value $<0,001$, so it can be concluded that there is a difference on the level of cadres as the PMO and without cadres as the PMO. With the result, can be interpret that the cadres as the PMO are optimal for enhancement of hemoglobin level in the prevention of anemia on pregnant woman. The efforts made towards the prevention if anemia is to activate all the health worker and the cadres to increase the regularity on consuming the Fe tablet of pregnant woman.

Keywords: Anemia; Cadres; hemoglobin level; Fe tablet

\section{PENDAHULUAN}

Organisasi Kesehatan Dunia World Health Organization (WHO) menyatakan bahwa untuk mencapai target MDGs penurunan angka kematian ibu antara 1990 dan 2015 seharusnya 5,5 persen pertahun. Namun data WHO, UNICEF, UNFPA dan Bank Dunia tahun 2015 menunjukkan angka kematian ibu 2 hingga saat ini penurunannya masih kurang dari satu persen per tahun. Pada 2005, sebanyak 536.000 perempuan meninggal dunia akibat masalah persalinan, lebih rendah dari jumlah kematian ibu tahun 1990 yang sebanyak 576.000. Menurut WHO secara global prevalensi anemia pada ibu hamil diseluruh dunia adalah sebesar $41,8 \%$, prevalansi anemia pada ibu hamil diperkirakan di Asia sebesar 48.2\%, Afrika 57.1\%, Amerika 24,1\% dan eropa 25.1\%. (WHO, 2015).

Menurut Simanjuntak dalam Manuaba (2010), mengemukakan bahwa sekitar $70 \%$ ibu hamil di
Indonesia mengalami anemia akibat kekurangan gizi. Pada pengamatan lebih lanjut menunjukkan bahwa kekurangan anemia yang diderita masyarakat adalah asupan $\mathrm{Fe}$ yang dapat diatasi dengan pemberian zat besi secara teratur.

Suplementasi tablet besi merupakan salah satu cara yang bermanfaat dalam mengatasi anemia. Di Indonesia, suplementasi besi sudah lama diberikan secara rutin pada 6ygvclbu hamil di Puskesmas dan Posyandu, menggunakan tablet yang mengandung 60 $\mathrm{mg} /$ hari dapat menaikan kadar $\mathrm{Hb}$ namun, terbukti dari prevalensi anemia pada lbu hamil yang masih tinggi baik di tingkat nasional maupun di tingkat jawa tengah (Prawirohardjo, 2008).

Berdasarkan hasil riset kesehatan dasar (Riskesdas) tahun 2013 pravelensi anemia pada ibu hamil di Indonesia sebesar $37,1 \%$, sedangkan angka kejadian ibu hamil anemia di Provinsi Jambi mencapai 
19.7\% dari keseluruhan ibu hamil. (Dinas Provinsi Jambi, 2017).

Berdasarkan latar belakang yang telah diuraikan di atas, maka penulis tertarik untuk melakukan penelitian tentang optimalisasi kader sebagai PMO ( petugas minum obat) dalam mengkonsumsi tablet Fe terhadap pencegahan anemia berbasis android diwilayah kerja puskesmas simpang kawat kota jambi tahun 2019.

\section{METODE PENELITIAN}

Metode penelitian dalam penelitian ini adalah penelitian Analitik dengan desain penelian Desain penelitian ini adalah kuasi eksperimental. Desain kuasi eksperimental adalah metode penelitian eksperimen dengan menggunakan kelompok kontro, yang bertujuan untuk mengetahui perbedaan kadar hemoglobin sebelum dan sesudah diawasi oleh kader sebagai PMO (Petugas Minum Obat) dalam mengkonsumsi tablet FE terhadap pencegahan anemia berbasis Android. Populasi penelitian ini adalah seluruh ibu hamil yang anemia pada bulan januari sampai juni 2019 di dilayah kerja Puskesmas Simpang Kawat Kota Jambi yaitu sebanyak 134 orang ibu hamil. Sampel dalam penelitian ini 30 kasus dan 30 kontrol. Teknik pengambilan sampel dalam penelitian ini dilakukan dengan teknik consecutive sampling. Penelitian ini telah dilaksanakan pada tanggal 11 Juli s/d 15 Agustus 2019. Pengumpulan data dilakukan secara langsung dan menggunakan aplikasi berbasis android yang dilakukan oleh kader terhadap responden. Hasil penelitian di analisis secara univariat untuk mengetahui rata-rata umur ibu, paritas dan usia kehamilan, dan bivariat untuk mengetahui perbedaan kadar hemoglobin sebelum dan sesudah diawasi oleh kader sebagai PMO (Petugas Minum Obat) dalam mengkonsumsi tablet FE terhadap pencegahan anemia berbasis Android

\section{HASIL DAN PEMBAHASAN Karakteristik responden}

Berdasarkan hasil penelitian yang telah dilakukan pada 30 responden sebagai kelompok eksperimen dan 30 responden sebagai kelompok kontrol dengan karakteristik responden umur ibu, paritas dan usia kehamilan. Hasil karakteristik responden adalah sebagai berikut:

Tabel 1. Karakteristik responden berdasarkan umur ibu, paritas, dan usia kehamilan

\begin{tabular}{lcccc}
\hline & Karakteristik responden & X1 & Kelompok & P-value \\
\hline Umur lbu & & $25,9 \pm 4,19$ & $26,23 \pm 3,08$ & $0,057^{*}$ \\
Paritas & Mean \pm SD & $2,4 \pm 0,49$ & $2,4 \pm 0,49$ & $0,509^{*}$ \\
Usia Kehamilan & & $24,90 \pm 5,51$ & $23,30 \pm 5,81$ & $0,606^{*}$ \\
\hline
\end{tabular}

Keterangan:

$\mathrm{X} 1 \quad=$ Kader sebagai PMO

$\mathrm{X} 2=$ tanpa kader Sebagai PMO

$\left.{ }^{*}\right)$ Homogenity Independent $t$-test is Significant at $>0,05$ level

Berdasarkan Pada Tabel 1 dapat diinterpretasikan rata-rata umur ibu, paritas dan usia kehamilan adalah homogen dengan nilai $p$-value $>0,05$ yang berarti tidak ada perbedaan karakteristik pada kelompok kader sebagai PMO dan tanpa kader sebagai PMO

Berdasarkan Tabel 1 tentang karakteristik responden yaitu umur ibu, paritas dan usia kehamilan dapat diinterpretasikan bahwa karakteristik responden adalah homogen atau sama antar kedua kelompok. Hal ini berarti pada kedua kelompok tidak memiliki perbedaan umur ibu, paritas dan usia kehamilan. Hasil analisis karakteristik umur responden menunjukkan bahwa rata-rata umur responden pada kelompok intervensi kader sebagai PMO adalah 25,9. Rata-rata umur responden pada kelompok tanpa kader sebagai PMO adalah 26,2 yang berarti tidak ada perbedaan umur ibu (usia produktif). Menurut Potter dan Perry (2006) pola pikir dan perilaku seseorang selalu berubah sepanjang kehidupannya seiring dengan pertambahan usia. Perkembangan emosional individu akan sangat mempengaruhi perilaku kesehatan, sehingga kematangan emosional dan peningkatan pengetahuan seiring dengan pertambahan usia individu

Usia reproduksi sehat adalah umur antara 20-35 tahun. Menurut Notoatmodjo (2010) pada umur 20-35 tahun merupakan waktu reproduksi yang paling baik dan memiliki sedikit risiko. Hubungan usia dengan anemia bahwa pada umur < 20 tahun dapat menyebabkan anemia karena pada umur tersebut perkembangan biologis dalam hal ini alat reproduksi belum optimal. Pada usia belia tersebut, psikis ang belum matang akam juga menyebabkan wanita hamil mudah mengalami guncangan mental yang mengakibatkan kurangya perhatian terhadap pemenuhan kebutuhan zat-zat gizi selama kehamilannya. Selain usia dibawah 20 tahun, kehamilan dengan usia diatas 35 tahun juga merupakan usia beresiko tinggi. Wanita yang hamil dalam usis terlalu tua yaitu $>35$ tahun pun akan rentan terhadap anemia. Hal ini terkait dengan penurunan daya tahan tubuh sehingga mudah terkena berbagai infeksi selama kehamilan (Amiruddin dan Wahyuddin, 2004).

Hasil karakteristik responden menunjukkan bahwa rata-rata paritas pada kelompok yang diberi intervensi kader sebagai PMO adalah 2.4. Nilai rata-rata paritas pada kelompok tanpa intervensi kader sebagai PMO adalah 2,4. Paritas merupakan banyaknya kelahiran hidup yang di miliki oleh seorang wanita. Anemia bisa terjadi pada ibu dengan paritas tinggi terkait dengan keadaan biologis ibu dan asupan zat gizi, hubungan kadar $\mathrm{Hb}$ dengan paritas dalam SKRT 2005 menunjukkan bahwa prevalensi anemia ringan dan berat akan lebih tinggi seiring dengan bertambahnya paritas. Prevalensi anemia ringan 1-4 lebih tinggi daripada paritas 0 yaitu $70,5 \%$ sedangkan pada paritas $<5$ prevalensi lebih tinggi daripada paritas $1-4$ yaitu $72,9 \%$ dan untuk anemia berat $7,6 \%$ pada paritas $1-4$ anemia berat hanya $3,5 \%$ dan pada paritas 0 sebesar $2,9 \%$. Makin sering seorang wanita mengalami kehamilan dan 
persalinan maka makin banyak kehilangan zat besi dan menjadi semakin anemia. Paritas $>4$ merupakan paritas yang berisiko mengalami anemia dalam kehamilan.(Murtini 2004)

Paritas merupakan salah satu faktor penting dalam kejadian anemia zat besi pada ibu hamil. Menurut Manuaba (2010), wanita yang sering mengalami kehamilan dan melahirkan makin anemia karena banyak kehilangan zat besi, hal ini disebabkan selama kehamilan wanita menggunakan cadangan besi yang ada di dalam tubuhnya (Salmariantyty, 2012).

Hasil analisis menunjukkan bahwa rata-rata usia kehamilan 24,9 pada kelompok intervensi kader sebagai PMO. Nilai rata-rata usia kehamilan ibu tanpa intervensi kader sebagai PMO adalah 23,3. Anemia pada ibu hamil secara fisiologis terjadi akibat adanya pengenceran darah, akibat peningkatan volume darah selama dalam masa kehamilan yang lazim disebut hidraemia atau hipervolemia. Pertambaha sel darah kurang dibandingkan dengan bertambahnya plasma hingga terjadi pengenceran darah. Perbandingan tersebut adalah sebagai berikut plasma (30\%), sel darah (18\%), dan hemoglobin (19\%). Bertambahnya darah dalam kehamilansudah mulai sejak kehamilan 10 minggu dan mencapai puncaknya dalam kehamilan antara 32 dan 36 minggu (Wiknjosastro,2002). Hal ini sejalan dengan hasil penelitian Riswan (2001) yang dilakukan di kota madya medan menunjukkan kejadian anemia pada trimester II(dua), dan trimester III (tiga) mencapai 70\%.

\section{Optimalisasi kader sebagai PMO (petugas minum obat) dalam mengkonsumsi tablet Fe terhadap pencegahan anemia}

Tabel 2. Perbedaan selisih kadar Hb pada kelompok kader sebagai PMO dan tanpa kader sebagai PMO

\begin{tabular}{|c|c|c|c|c|c|}
\hline \multirow{2}{*}{ Kelompok } & \multirow{2}{*}{ Mean \pm SD } & \multirow{2}{*}{ Mean difference } & \multicolumn{2}{|c|}{$95 \% \mathrm{Cl}$ of the Difference } & \multirow{2}{*}{ p-value } \\
\hline & & & Lower & Upper & \\
\hline $\mathrm{X} 1$ & $1,75 \pm 0,59$ & \multirow{2}{*}{1,58} & \multirow{2}{*}{1,29} & \multirow{2}{*}{1,86} & \multirow{2}{*}{$<0,001^{*}$} \\
\hline $\mathrm{X} 2$ & $0,17 \pm 0,51$ & & & & \\
\hline
\end{tabular}

Berdasarkan Tabel 2 didapatkan hasil rata-rata kenaikan $\mathrm{Hb}$ sebesar 1,75 yang di interpretasikan dengan nilai $p$-value $<0,001$ sehingga dapat disimpulkan bahwa terdapat perbedaan kadar $\mathrm{Hb}$ sebelum dan sesudah dilakukan intervensi kader sebagai PMO. Menurut WHO (2000) kadar hemoglobin indikator anemia pada ibu hamil ialah $\mathrm{Hb}<11 \mathrm{gr} \%$.

Anemia adalah kondisi dimana sel dalah merah atau hemoglobin menurun, sehingga kapasitas daya angkut oksigen untuk kebutuhan organ-organ vital pada ibu hamil dan janin menjadi berkurang. Indikasi anemia adalah jika konsentrasi hemoglobin kurang dari 10.5 sampai 11,0 gr/dl (Varney, 2006). Menurut Rustam (1998), penyebab sebagian besar anemia di Indonesia adalah kekurangan zat besi yang diperlukan untuk pembentukan hemoglobin disebut anemia defisiensi besi. Anemia pada ibu hamil membawa akibat dan komplikasi yang berisiko tinggi untuk terjadinya keguguran, perdarahan, BBLR, atonia uteri, inersia uteri, retensio plasenta.

Suplementasi tablet besi merupakan salah satu cara yang bermanfaat dalam mengatasi anemia. Di Indonesia, suplementasi besi sudah lama diberikan secara rutin pada lbu hamil di Puskesmas dan Posyandu, menggunakan tablet yang mengandung 60 $\mathrm{mg} /$ hari dapat menaikan kadar Hb. Menurut Siswono dalam Mandrasekar (2007), cara mencegah anemia defisiensi besi antara lain dengan mengkonsumsi sayuran hijau, daging, hati dan produk olahan susu, mengkonsumsi suplemen zat besi, mengkonsumsi vitamin $\mathrm{C}$ untuk membantu proses penyerapan zat besi dalam saluran pencernaan, menghindari kafein, misalnya kopi/teh dalam jumlah banyak karena dapat menggangu penyerapan zat besi. Adapun upaya penanggulangan anemia defisiensi besi yang mudah dan murah adalah dengan pemberian tablet besi folat
(Fe). Sejauh ini hasil yang dicapai belum optimal, terbukti dari prevalensi anemia pada lbu hamil yang masih tinggi baik di tingkat nasional maupun di tingkat jawa tengah (Prawirohardjo, 2002).

Berdasarkan hasil wawancara singkat dengan beberapa responden menyatakan bahwa ibu hamil telah mendapat tablet Fe setiap kali kunjungan antenatal care, namun kenyatanya ibu hamil tidak minun secara teratur dan sering lupa untuk mengkonsumsi obat penambah darah tersebut sehingga menjadi salah satu penyebab terjadinya anemia. Dalam hal ini sesuai dengan penelitian yang dilakukan peneliti memberikan kader sebagai $\mathrm{PMO}$ ( petugas minum obat) yang berfungsi untuk mengawasi ibu hamil dalam mengkonsumsi tablet Fe terhadap pencegahan anemia berbasis android, yang mana ibu hamil akan selalu dipantau untuk memastikan selalu mengkonsumsi tablet Fe.

Pada tabel hasil penelitian yang telah dilakukan terhadap 30 responden pada kelompok eksperimen dan 30 responden pada kelompok kontrol didapatkan hasil uji independent $t$-test untuk mengetahui Optimalisasi kader sebagai PMO (petugas minum obat) dalam mengkonsumsi tablet Fe Terhadap peningkatan kadar $\mathrm{Hb}$ sebagai upaya pencegahan anemia di interpretasikan nilai $p$-value 0,084 sehingga dapat disimpulkan bahwa tidak terdapat perbedaan kadar $\mathrm{Hb}$ sebelum dan sesudah tanpa intervensi kader sebagai PMO dengan selisih 0,17 .

Peran kader dimaksudkan untuk mempasilitasi keteraturan atau kepatuhan ibu hamil dalam mengkonsumsi tablet Fe. Dalam penelitian ini kader berfungsi sebagai pengawas dalam mengkonsumsi tablet Fe dilengkapi dengan aplikasi berbasis android yang mana kader akan memferivikasi setiap dokumentasi yang dikirimkan ibu hamil melalui androidnya setiap hari pada saat mengkonsumsi obat 
penambah darah, sebagai suatu bentuk keteraturan atau kepatuhan ibu hamil dalam mengkonsumsi tablet Fe, dalam aplikasi dilengkapi dengan notifikasi pemberitahuan sebagai penginggat setiap kali ibu lalai dalam mengkonsumsi tablet $\mathrm{Fe}$, pemberitahuan tersebut akan muncul 3 kali dalam 24 jam namun tidak akan muncul setelah ibu hamil mengkonsumsi tamblet Fe dan mengirimkan dokumentasi pada aplikasi yang langsung bersinggungan dengan kader dengan demikian memungkinkan ibu hamil taat dan teratur dalam mengkonsumsi tablet $\mathrm{Fe}$ dengan monitoring kader sebagai petugas minum obat.

Kepatuhan dalam mengkonsumsi tablet besi adalah ketaatan ibu hamil melaksanakan anjuran petugas kesehatan untuk mengkonsumsi tablet zat besi. Kepatuhan mengkonsumsi tablet zat besi di ukur dari ketepatan jumlah tablet yang dikonsumsi, ketepatan cara mengkonsumsi tablet zat besi, frekuensi konsumsi perhari. Suplementasi besi atau pemberian tablet $\mathrm{Fe}$ merupakan salah satu upaya penting dalam mencegah dan menanggulangi anemia, khususnya anemia kekurangan besi. Suplementasi besi merupakan cara efektif karena kandungan besinya yang dilengkapi asam folat yang dapat mencegah anemia karena kekurangan asam folat (Afnita, 2004). Ketidakpatuhan ibu hamil meminum tablet zat besi dapat memiliki peluang yang lebih besar untuk terkena anemia. Sejalan dengan penelitian yang dilakukan hidayah (2012) menunjukkan Hasil uji statistik dengan menggunakan uji Chi Square diperoleh ada hubungan antara kepatuhan ibu hamil mengkonsumsi tablet $\mathrm{Fe}$ dengan kejadian anemia di Desa Pageraji Kecamatan Cilongok Kabupaten Banyumas dengan nilai $p=0,005$. Artinya semakin baik kepatuhan ibu dalam mengkonsumsi tablet Fe maka semakin rendah resiko ibu mengalami anemia.

Dalam aplikasi berbasis android dilengkapi dengan informasi yang berkaitan dengan anemia diantaranya penyebab anemia, efek samping yang ditimbulkan dari anemia baik ibu maupun janin dalam kandungan maupun setelah lahir, cara pencegahan dan penanggulangan anemia itu sendiri. Menurut Never (2002) dalam Wipayani (2008), faktor-faktor yang mempengaruhi kepatuhan ibu hamil meminum tablet zat besi yaitu 1) Pengetahuan yakni Pengetahuan ibu hamil tentang anemia dan manfaat dari zat besi didapat dari penyuluhan yang diberikan bidan pada waktu ibu hamil tersebut melakukan pemeriksaan ANC. Tingkat pengetahuan ibu juga mempengaruhi kepatuhan ibu hamil dalam mengkonsumsi tablet zat besi.2) Tingkat Pendidikan adalah Latar belakang pendidikan ibu hamil juga sangat berpengaruh terhadap kepatuhan ibu hamil meminum tablet zat besi.3) Pemeriksaan ANC mempengaruhi tingkat kepatuhan ibu hamil dalam mengkonsumsi tablet $\mathrm{Fe}$, karena dengan melakukan pemeriksaan kehamilan ibu hamil akan mendapat informasi tentang pentingnya tablet $\mathrm{Fe}$ bagi kehamilannya.

Dalam hal ini penelitian dilakukan dalam upaya meningkatkan kadar $\mathrm{Hb}$ sebagai upaya pencegahan anemia maupun penanggulangan kejadian anemia ibu hamil. Upaya yang dilakukan melalui bantuan kader menggingat dampak yang ditimbulkan sangat berpengaruh bagi ibu dan janin seingga perlu penanganan yang intensif oleh tenaga kesehatan, dalam hal ini melalui pemberdayaan kader yang berperan langsung sebagai pegawas dalam memonitor ibu hamil mengkonsumsi tablet $\mathrm{Fe}$ berbasis android. Sehingga dengan adanya peran kader sebagai PMO berbasis android dapat meningkatkan kepatuhan mengkonsumsi tablet Fe yang berdampak terhadap penurunan kejadian anemia yang menjadi pemicu kematian ibu dan bayi. Oleh karena itu sangat penting bagi puskesmas untuk mensosialisasikan kepada seluruh kader terkait peran kader sebagai PMO berbasi android sebagai upaya pencegahan anemia pada ibu hami.

\section{SIMPULAN}

Dari hasil penelitian dapat di simpulkan terdapat perbedaan kadar $\mathrm{Hb}$ dengan nilai $p$-value $<0,001$ pada kelompok kader sebagai PMO lebih baik di bandingkan kelompok tanpa kader sebagai PMO

\section{DAFTAR PUSTAKA}

Amirudin, dkk. 2004. Studi Kasus Kontrol Faktor Biomedis Terhadap Kejadian Anemia Ibu Hamil Di Puskesmas Bantimurung Maros tahun 2004

Arikunto. (2010). Prosedur penelitian suatu pendektan praktis. Jakarta: Rineka Cipta

DepkesGi. (2012). Gizi dan Kesehatan Masyarakat. Jakarta

Depkes RI. (2015) Profil Kesehatan Indonesia. Jakarta

Dinkes Provinsi Jambi. (2013). Data Ibu hamil yang mengalami anemia .Jambi

(2015). Data Ibu hamil yang mengalami anemia .Jambi

(2016). Data Ibu hamil yang mengalami anemia .Jambi

Ibrahim.M. (2010). Nutrisi Janin dan Ibu hamil Cara Membuat Otak Janin Cerdas. Yogyakarta : Nuha Medika

Indrati. (2014). Pendidikan Konsumsi Pangan. Jakarta : Kencana Prenadamedia Group.

Kristianasari.W. (2010). Gizi Ibu Hamil . Yogyakarta :Nuha Medika

Manuaba . (2008). IImu dan Kebidanan Penyakit Kandungan dan KB. Jakarta : EGC

(2009). Ilmu dan Kebidanan Penyakit Kandungan dan KB. Jakarta : EGC (2010). Ilmu Kebidanan dan Penyakit Kandungan dan KB. Jakarta : EGC (2013). Ilmu Kebidanan dan Penyakit Kandungan dan KB. Jakarta : EGC

Mochtar, R. (1998). Sinopsis Obstetri. Jakarta: EGC

Murtini, Efektifitas Suplementasi Tablet Besi Dan Vitamin C Terhadap Kader Hemoglobin Ibu Hamil Di Wilayah Kerja Puskesmas Bantimurung Kabupaten Maros. Program pasca sarjana UNHAS 2004

Naga,S .2012. Buku Panduan Lengkap IImu Penyakit Dalam.Yogyakarta : Diva Press

Notoatmodjo (2007). Kesehatan masyarakat ilmu dan seni. Jakarta : Rineka Cipta

(2010). Metode penelitian kesehatan. Jakarta : Rineka Cipta 
(2013) Promosi Kesehatan Masyarakat Global. Jakarta : Rineka Cipta

Potter, A. and Perry, A. G. (2006) 'Buku Ajar Fundamental Keperawatan: Konsep, Proses, Dan Praktik', in. Jakarta: EGC.

Prawihardjo . (2008). Ilmu Kebidanan. Jakarta : PT. Bina Pustaka

Proverawati. (2009). IImu Gizi Kebidanan. Yogyakarta : EGC

Puskesmas Tanjung Pinang. (2015). Data Ibu hamil yang berada di Puskesmas Tanjung Pinang . Jambi

Riskesdas. (2013). Prevalensi kejadian anemi dalam Profil Kesehatan Indonesia.Jakarta

Salmariantity. (2012). Faktor-Faktor Yang Berhubungan Dengan Anemia Pada Ibu Hamil Di Wilayah Kerja Puskesmas Gajah Mada Tembilahan Kabupaten Indragiri Hilir Tahun 2012. Jakarta: FK UI

Sarwono. (2007). Ilmu Kebidanan. Jakarta : PT. Bina Pustaka

Sastroasrmoro dan Ismael. 2010. Metodologi Penelitian. Jakarta: Rineka Cipta

Sugiono (2010). Metode penelitian kuantitatif. Kuantitatif dan R\&D Alfabeta, Bandung

Tarwoto (2007). Buku Saku Anemia Pada Ibu Hamil Konsep dan Penatalaksanaan. Jakarta : Trans Info Media

Waryana. (2010). Gizi Reproduksi. Yogyakarta : Pustaka Rihama

Winkjosastro, H (2005) IImu Kebidanan. Jakarta: Yayasan Bina Pustaka Sarwono Prawiroharjo

WHO .(2009). Buku Saku Pelayanan Kesehatan Anak Di Rumah Sakit. WHO

Walyani.E. (2015). Asuhan Kebidanan Pada Kehamilan .Yogyakarta : Pustaka Baru Press 